\title{
Niat Ibu Hamil untuk Tes HIV di UPT (Unit Pelayanan Terpadu) Puskesmas Alun-Alun Kabupaten Gresik
}

\author{
Ernawati*), Antono Suryoputro**), Syamsulhuda BM**) \\ *) Alumni Magister Promosi Kesehatan Universitas Diponegoro Semarang \\ Korespondensi : nawae_nawang@yahoo.co.id/085732081181 \\ **) Magister Promosi Kesehatan Universitas Diponegoro Semarang
}

\begin{abstract}
ABSTRAK
Penularan infeksi HIV dari ibu ke anak merupakan penyebab utama infeksi HIV pada anak usia di bawah 15 tahun. Pemeriksaan HIV pada ibu hamil merupakan peluang yang baik dalam upaya mencegah penularan HIV dari ibu ke bayi, dimana semua ibu hamil ditawarkan untuk melakukan tes HIV. Penelitian ini bertujuan untuk mengetahui faktor-faktor penyebab niat ibu hamil untuk tes HIV di UPT Puskesmas Alun-Alun Kabupaten Gresik tahun 2015. Jenis penelitian ini adalah explanatory research dengan pendekatan cross sectional. Subyek penelitian ini adalah ibu hamil yang melakukan pemeriksaan antenatal care di UPT Puskesmas Alun-Alun Kabupaten Gresik menggunakan teknik purposive sampling dengan jumlah sampel 125 orang. Penelitian ini menggunakan analisis hubungan menggunakan Chi Square dan analisis multivariat dengan menggunakan analisis regresi logistik. Hasil penelitian menunjukkan bahwa Ibu hamil yang berniat untuk tes HIV sebanyak 54,4\%, sedangkan yang kurang niat sebanyak $45,6 \%$. Variabel yang berpengaruh secara signifikan terhadap niat ibu hamil untuk tes HIV, yaitu pengetahuan tentang tes HIV, persepsi keparahan penyakit HIV dan peran bidan dalam memberikan penyuluhan. Diharapkan dapat mengembangkan sosialisasi VCT bekerjasama dengan instansi kesehatan swasta, kader, dan kelurahan dalam memberikan informasi mengenai layanan VCT.
\end{abstract}

Kata kunci : Niat Tes HIV, Ibu Hamil, Puskesmas

\section{ABSTRACT}

The spreading of HIV infection from mother to child is the main cause of HIV infection towards child below fifteen years old. The examination of HIV towards pregnant mother is a good opportunity to protect the spreading of HIV from mother to baby, wherein all pregnant mothers are suggested to have HIV test. This research aims to know factors of pregnant mother's intention to get HIV test at UPT (Integrated Service Unit) of Public Health Center of Gresik Regency Town Square in 2015. Explanatory research which uses survey method with cross sectional approach. The samples of this research is pregnant mothers who carry out antenatal care examination at UPT (Integrated Service Unit) of Public Health Center of Regency Town Square uses purposive sampling technique with the amount of samples as many as 125 peoples. This research uses questionnaire instruments. Its relation analysis uses Chi Square and multivariate analysis by using logistic regression. Of research indicates that pregnant mothers who intend to get HIV test are 54,4\%, while those less intend are 45,6\%. Variables which are related to pregnant mother's intention to do HIV test are knowledge about HIVIAIDS, HIV test, perception of severity, self efficacy, and midwife's role in giving counseling. UPT (Integrated Service Unit) of Public Health Center of Gresik Regency Town Square is aimed to develop VCT socialization in cooperating with private healthcare institution, cadre, and village in giving information about VCT service.

Keywords: intention of having HIV test, pregnant mother, Public Health Center 


\section{PENDAHULUAN}

Faktor yang berkontribusi terhadap kematian ibu, secara garis besar dapat dikelompokkan menjadi penyebab langsung, penyebab tidak langsung dan faktor lain. Faktor lain yang berpengaruh adalah ibu hamil yang menderita penyakit menular seperti malaria, HIV/AIDS, tuberkulosis, sifilis, sedangkan penyakit tidak menular seperi hipertensi, diabetes mellitus, jantung, gangguan jiwa, maupun yang mengalami kekurangan gizi. HIV pada ibu hamil, selain mengancam keselamatan ibu juga dapat menularkan kepada bayinya (Mother To Cild transmission) menurut data kementerian kesehatan tahun 2011, dari 21.103 ibu hamil yang menjalani tes HIV sebanyak $534(2,6 \%)$ ibu hamil dinyatakan positif HIV (Kementerian Kesehatan Republik Indonesia, 2012).

\section{Penularan}

$$
\text { infeksi }
$$

Human

Immunodeficienxy Virus (HIV) dari ibu ke anak merupakan penyebab utama infeksi HIV pada anak usia di bawah 15 tahun. Hampir sebagian besar penderita tersebut tertular melalui penularan dari ibu ke anak. Setiap tahun diperkirakan lebih dari 800.000 bayi menjadi terinfeksi HIV akibat penularan dari ibu ke anak (Judarwanto, 2010). Dalam publikasi rekomendasi WHO maupun UNAIDS tahun 2010 dikatakan bahwa terdapat 33,4 juta orang dengan HIV/AIDS di seluruh dunia sebanyak 15,7 juta (47\%) diantaranya adalah perempuan dan 2.1 juta anak-anak berusia kurang dari 15 tahun.

Di Indonesia, tahun 2014, 55.799 kasus AIDS dan 150.296 kasus HIV. Jumlah kasus HIV tertinggi yaitu DKI Jakarta (32.782), diikuti Jawa Timur (19.249), Papua (16.051). Jumlah AIDS terbanyak dilaporkan dari Papua (10.184), Jawa Timur (8.976), DKI Jakarta (7.477). Kasus AIDS tertinggi umur 20-29 tahun $(32,9 \%)$. Presentase AIDS pada laki-laki sebanyak $54 \%$ dan perempuan $29 \%$ dan $17 \%$ tidak melaporkan jenis kelamin. Jumlah AIDS tertinggi adalah pada ibu rumah tangga (6.539). Faktor resiko penularan terbanyak melalui heteroseksual $(61,5 \%)$, penasun $(15,2 \%)$, perinatal $(2,7 \%)$ dan homoseksual $(2,4 \%)$. Dengan angka kematian (CFR) menurun dari $3,79 \%$ tahun 2012 menjadi 0,46\% pada tahun 2014 (Direktorat Jenderal Pengendalian Penyakit dan Penyehatan Lingkungan, 2014). Provinsi Jawa Timur sampai bulan September 2014, kasus HIV sebanyak (19.249), dan kasus AIDS sebanyak (8.976). Kabupaten Gresik tahun 2014 menerangkan bahwa jumlah kasus HIV/AIDS 530 kasus yang dilaporkan, berdasarkan faktor resiko penularan adalah heteroseksual 244, narkoba 6, lain-lain 19. Profil Kesehatan Kabupaten Gresik berdasarkan kelompok umur yaitu 25-49 tahun pada tahun 2012 (128), tahun 2013 
(190), 2014 (152), sampai bulan maret 2015 (22), (Dinas Kesehatan Kabupaten Gresik, 2011). Pada anak umur kurang dari lima tahun terdapat lima kasus dan ada dua ibu meninggal setelah melahirkan dan setelah di tes ternyata positif HIV. Sedangkan sampai bulan Desember tahun 2014 terdapat dua ibu hamil dengan HIV/AIDS dengan jumlah kasus baru 91. Diperkirakan masih banyak kasus yang belum atau tidak dilaporkan (Dinas Kesehatan Kabupaten Gresik, 2011).

Ibu hamil yang ada di Indonesia sebanyak 4.372.600 ibu hamil, hanya $5.167(0,1 \%)$ ibu hamil yang melakukan pemeriksaan HIV, dimana 1.306 ibu hamil (25\%) diantaranya positif HIV. Menurut WHO, sampai $30 \%$ bayi lahir dari ibu yang terinfeksi HIV akan tertular HIV kalau ibunya tidak memakai terapi antiretroviral (ART). Risiko penularan HIV dari ibu ke anak tersebut diperkirakan 5-10\% selama kehamilan, 10-20\% selama persalinan dan 5\%-10\% selama menyusui (Lusia, 2015).

Infeksi HIV dari ibu ke anak dapat dicegah, melalui upaya pencegahan penularan dari ibu ke anak yang merujuk dari rekomendasi WHO tahun 2010, dimana pada dasarnya semua ibu hamil ditawarkan tes HIV. Cakupan ibu hamil yang sudah melakukan tes HIV di Indonesia masih rendah yaitu $<1 \%$. Upaya pencegahan penularan HIV/AIDS dari ibu ke bayi adalah dengan program PMTCT
(Prevention of Mother to Child Transmission). Program PMTCT dalam pelaksanaannya ada empat pilar. (1), mencegah terjadinya penularan HIV pada perempuan usia reproduktif. (2), mencegah kehamilan yang tidak direncanakan pada ibu dengan HIV. (3), mencegah terjadinya penularan HIV dari ibu hamil dengan HIV kepada bayi yang dikandungnya. (4), memberikan dukungan psikologis, sosial, dan perawatan kepada ibu dengan HIV beserta bayi dan keluarganya. VCT (Voluntary Counseling and Testing) adalah layanan tes, konseling, dukungan, akses untuk terapi suportif, terapi infeksi oportunistik, dan ART (Antiretroviral Therapy). Terdapat $22.834 \mathrm{ibu}$ hamil yang diberi konseling PMTCT pada tahun 2012, tetapi hanya 160 ibu hamil $(0,04 \%)$ yang melakukan VCT. Sedangkan pada tahun 2013 hanya $0,02 \%$ yang melakukan VCT. Puskesmas adalah layanan kesehatan primer di masyarakat, harus menjadi ujung tombak dalam upaya PMTCT. Layanan kesehatan ibu dan anak (KIA) yang terintegrasi Puskesmas secara komprehensif dapat menjadi penapisan terdepan untuk pendeteksian sedini mungkin, utamanya pada prong 3 yaitu mencegah terjadinya penularan HIV dari ibu hamil HIV positif ke bayi yang dikandungnya. Dengan demikian resiko penularan HIV pada bayi yang dikandung dari ibu HIV positif bisa ditekan. Karena 
itu peran layanan KIA di Puskesmas menjadi sangat penting (Departemen Kesehatan Republik Indonesia, 2008).

Berdasarkan hasil wawancara terhadap $15 \mathrm{ibu}$ hamil yang melakukan kunjungan ANC di Puskesmas, 5 ibu hamil yang bersedia ikut tes dan $10 \mathrm{ibu}$ hamil tidak ikut tes karena merasa tidak berisiko. Alasan menolak tes HIV oleh ibu hamil, karena merasa tidak memiliki faktor risiko untuk tertular HIV, takut dengan hasil jika dilakukan tes, takut dengan pandangan negatif orang yang melihat ketika mengunjungi klinik VCT, khawatir pandangan masyarakat bila ketahuan positif HIV, ibu bekerja sehingga tidak ada waktu untuk melakukan tes HIV serta tidak mendapatkan ijin dari pasangan atau suami.

Tujuan penelitian ini adalah mengetahui faktor-faktor penyebab niat ibu hamil untuk tes HIV di UPT Puskesmas Alun-Alun Kabupaten Gresik tahun 2015.

\section{METODE}

Jenis penelitian ini adalah penelitian kuantitatif, menggunakan rancangan penelitian penjelasan (explanatory research) dengan pendekatan cross sectional. Variabel dependen penelitian ini adalah niat untuk tes HIV pada ibu hamil, sedangkan variabel independen meliputi karakteristik karakteristik ibu hamil terdiri dari umur, tingkat pendidikan, status pernikahan, pekerjaan, paritas, pekerjaan suami, pengetahuan tentang HIV, pengetahuan tentang tes HIV, persepsi tentang kerentanan terkena HIV, persepsi tentang keparahan terkena HIV, persepsi tentang efektivitas mengikuti tes HIV, persepsi tentang kemampuan diri yang dimiliki ibu hamil untuk tes HIV, peran bidan dalam memberikan penyuluhan/PITC pada ibu hamil untuk tes HIV.

Populasi dalam penelitian ini adalah semua ibu hamil yang ditemukan pada saat pemeriksaan antenatal care di UPT Puskesmas Alun-Alun Kabupaten Gresik yaitu berjumlah $125 \mathrm{ibu}$ hamil.

Teknik pengambilan sampel yang digunakan dalam penelitian ini adalah purposive sampling dimana variabel terikat dalam penelitian ini adalah niat untuk tes HIV pada ibu hamil

Sumber data dalam penelitian terdiri dari data primer yaitu dari hasil angket oleh ibu hamil di dalam satu ruangan berupa pertanyaan tertulis untuk mengungkap niat ibu hamil untuk tes HIV dan adanya kebebasan dalam menjawab kuesioner tanpa pengaruh dari orang lain serta data sekunder yang meliputi laporan hasil penelitian, jurnal, referensi atau leteratur dari berbagai sumber buku dan media, laporan jumlah ibu hamil dan data laporan buku KIA tersebut. Sedangkan untuk membuktikan keabsahan kuesioner 
yang digunakan dalam penelitian ini $\mathrm{Uji}$ validitas dan reliabilitas dilakukan kepada ibu hamil yang berjumlah 30. Uji Validitas dengan menggunakan uji korelasi product moment, sedangkan uji reliabilitas menggunakan uji statistik alpha cronbach (r alpha).

Data yang telah terkumpul dianalisis univariat dengan cara distribusi frekuensi, sedangkan analisis bivariat dengan cara tabulasi silang dan kemudian dilakukan analisis statistik menggunakan uji chi-square dan dilanjutkan dengan analisis multivariat menggunakan metode regresi logisitik.

\section{HASIL DAN PEMBAHASAN}

\section{Karakteristik Responden}

\section{Umur}

Berdasarkan hasil analisis univariat terhadap $125 \mathrm{ibu}$ hamil, sebagian besar besar ibu hamil pada kelompok usia $\geq 25$ tahun $(74,4 \%)$ sedangkan ibu hamil dengan umur < 25 tahun $(25,6 \%)$. Hasil uji statistik menggunakan uji Chi Square $\left(X^{2}\right)$ dengan taraf signifikansi $5 \%$ didapatkan nilai $\mathrm{p}$ sebesar 0,867 (nilai $\mathrm{p}>0,05$ ). Hal ini menunjukkan bahwa tidak ada hubungan antara umur dengan niat ibu hamil untuk tes HIV. Hasil penelitian ini sejalan dengan apa yang diungkapkan oleh Bowes (2011), umur responden yang makin dewasa akan mudah beradaptasi dengan lingkungan yang ada disekitarnya dimana mereka mau mengikuti perilaku dalam melakukan tes HIV dikarenakan pengaruh akan lingkungan yang ada di sekitarnya seperti keterpaparan dengan sumber informasi, suami dan teman yang akan bertambah sejalan dengan bertambahnya umur.

Pada usia yang semakin tua maka seseorang semakin banyak pengalamannya sehingga pengetahuannya semakin bertambah. Karena pengetahuannya banyak maka seseorang akan lebih siap dalam menghadapi sesuatu. Hal ini menunjukkan bahwa kesediaan ibu hamil untuk melakukan tes HIV tidak terkait dengan usia para ibu hamil, meskipun seharusnya responden dengan usia dewasa lebih banyak yang melakukan pemeriksaan VCT daripada yang tidak karena kedewasaannya dalam berfikir mampu menghadapi dan beradaptasi dengan sesuatu yang baru. Serta mampu mengambil keputusan sendiri tanpa bantuan dari suami atau orang tua atau bahkan mertua.

\section{Pendidikan}

Berdasarkan tingkat pendidikan diperoleh hasil bahwa sebagian besar ibu hamil memiliki pendidikan berpendidikan tinggi $(52,9 \%)$ sedangkan yang berpendidikan dasar/menengah (42,9\%). Hasil uji statistik menggunakan uji $C h i$ Square $\left(X^{2}\right)$ dengan taraf signifikansi $5 \%$ 
didapatkan nilai $\mathrm{p}$ sebesar 0,314 (nilai $\mathrm{p}$ > 0,05). Hal ini menunjukkan bahwa tidak ada hubungan antara tingkat pendidikan dengan niat ibu hamil untuk tes HIV.

Pendidikan yang rendah dapat menyebabkan timbulnya pola pemikiran yang irasional dan adanya kepercayaankepercayaan kepada takhayul. Ibu yang seperti ini akan sulit menerima hal-hal baru (Notoatmojo, 2003). Semakin tinggi pendidikan seorang wanita maka semakin mampu mandiri dengan sesuatu yang menyangkut diri mereka sendiri. Semakin tinggi pendidikan semakin menyadari untuk segera melakukan pemeriksaan pada bulan pertama kehamilannya (Maria D. dan Yuristianti G. 2000)

\section{Status Pernikahan}

Berdasarkan status pernikahn Ibu hamil lebih banyak terdapat pada kelompok dengan status menikah/pernah menikah (46,6\%) dibandingkan dengan status belum/tidak menikah (28,6\%). Hasil uji statistik menggunakan uji Chi Square $\left(X^{2}\right)$ dengan taraf signifikansi 5\% didapatkan nilai $\mathrm{p}$ sebesar 0,352 (nilai $\mathrm{p}>$ 0,05). Hal ini menunjukkan bahwa tidak ada hubungan antara status pernikahan dengan niat ibu hamil untuk tes HIV.

Ibu hamil dengan status tidak menikah memiliki kecenderungan untuk melakukan tes HIV, terlebih bagi yang hamil dengan pasangan tidak resminya.
Sementara bagi yang memiliki pasangan resmi (status menikah) merasa tidak perlu melakukan tes HIV, karena sudah mengetahui pasangannya dengan lebih baik.

\section{Pekerjaan}

Berdasarkan pekerjaan Ibu hamil lebih banyak terdapat pada pekerjaan yang tidak beresiko (48\%) dibandingkan yang beresiko (34,8\%). Hasil uji statistik menggunakan uji Chi Square $\left(X^{2}\right)$ dengan taraf signifikansi $5 \%$ didapatkan nilai $\mathrm{p}$ sebesar 0,249 (nilai $\mathrm{p}>0,05$ ). Hal ini menunjukkan bahwa tidak ada hubungan antara pekerjaan dengan niat ibu hamil untuk tes HIV.

Bekerja adalah salah satu upaya untuk mendapatkan pamasukan, dengan bekerja maka akan meningkatkan penghasilan sehingga dapat memenuhi kebutuhan dan meningkatkan kesejahteraan. Selain mendapatkan penghasilan, lingkungan pekerjaan akan memberikan pengalaman dan pengetahuan baik secara langsung maupun tidak langsung. Sejalan dengan penelitian yang dilakukan Sari (2014), Pengalaman yang kurang baik mendorong seseorang akan berusaha untuk melupakan, namun jika pengalaman terhadap obyek tersebut menyenangkan maka secara psikologis timbul kesan yang sangat mendalam dan membekas dalam emosi kejiwaannya, dan 
akhimya dapat pula membentuk sikap positif dalam kehidupannya.

\section{Paritas}

Berdasarkan hasil penelitian paritas Ibu hamil lebih banyak terdapat pada kelompok yand sudah pernah melahirkan $(48,1 \%)$ dibandingkan kelompok yang belum pernah melahirkan $(41,7 \%)$. Hasil uji statistik menggunakan uji Chi Square $\left(X^{2}\right)$ dengan taraf signifikansi $5 \%$ didapatkan nilai $\mathrm{p}$ sebesar 0,486 (nilai $\mathrm{p}>$ 0,05). Hal ini menunjukkan bahwa tidak ada hubungan antara paritas dengan niat ibu hamil untuk tes HIV. Kelahiran (paritas) bukan faktor yang mendorong seorang ibu hamil melakukan tes HIV kalau tidak didukung dengan pengetahuan serta pengetahuan merupakan bagian penting dalam mempengaruhi perilaku kesehatan seseorang.

\section{Pekerjaan suami}

Berdasarkan pekerjaan suami lebih banyak terdapat pada kelompok pekerjaan suami yang tidak beresiko (50\%) dibandingkan yang beresiko (39,2\%). Hasil uji statistik menggunakan uji Chi Square $\left(X^{2}\right)$ dengan taraf signifikansi 5\% didapatkan nilai $\mathrm{p}$ sebesar 0,234 (nilai $\mathrm{p}>$ 0,05). Hal ini menunjukkan bahwa tidak ada hubungan antara pekerjaan suami dengan niat ibu hamil untuk tes HIV. Pekerjaan suami adalah pekerjaan yang tidak beresiko atau rentan terkena HIV/AIDS. Sehingga tidak mempengaruhi niat ibu untuk melakukan tes HIV.

\section{Pengetahuan ibu hamil tentang HIVAIDS}

Berdasarkan pengetahuan ibu hamil tentang HIV/AIDS lebih banyak terdapat pada kelompok yang memiliki pengetahuan kurang baik $(57,7 \%)$ dibandingkan yang memiliki pengetahuan baik (37\%). Hasil uji statistik menggunakan uji Chi Square $\left(X^{2}\right)$ dengan taraf signifikansi $5 \%$ didapatkan nilai $\mathrm{p}$ sebesar 0,022 (nilai $\mathrm{p}<0,05$ ). Hal ini menunjukkan bahwa ada hubungan antara pengetahuan tentang HIV/AIDS dengan niat ibu hamil untuk tes HIV.

Dari hasil analisis regresi logistik (Analisis Multivariat) pengetahuan ibu hamil tentang HIVAIDS Nilai adjusted OR atau exp (B) variabel pengetahuan tentang tes HIV sebesar 2,67 dengan $\mathrm{p}=0.014$ ( $\mathrm{p}$ $<0,05)$, berarti pengetahuan yang baik mempunyai kemungkinan 2,67 kali berniat untuk tes HIV dibandingkan dengan pengetahuan yang kurang baik.

Allport (2016), menyatakan bahwa dalam menentukan sikap dan perilaku yang utuh, pengetahuan, pikiran, keyakinan, dan emosi memegang peranan penting. Pengetahuan merupakan strategi perubahan perilaku yang penting untuk menimbulkan kesadaran dan akhirnya 
berperilaku sesuai dengan pengetahuan yang dimilikinya. Berdasarkan teori adaptasi, apabila seseorang memiliki tingkat pengetahuan yang baik setidaknya dapat mendorong untuk mempunyai sikap dan perilaku yang baik pula.

Ibu hamil yang mempunyai pengetahuan yang baik tentang HIV/AIDS, akan mengubah perilakunya untuk melakukan tes HIV. Dengan pengetahuan tersebut diharapkan ibu hamil mau atau setidaknya memiliki keinginan untuk melakukan tes HIV dalam hal mencegah penularan HIV/AIDS. (Departemen Kesehatan Republik Indonesia, 2008).

\section{Kerentanan Terkena HIV}

Berdasarkan kerentanan Ibu hamil terkena HIV lebih banyak pada kelompok yang memiliki persepsi kerentanan kurang baik $(50,9 \%)$ dibandingkan yang memiliki persepsi kerentanan baik (41,2\%). Hasil uji statistik menggunakan uji Chi Square $\left(X^{2}\right)$ dengan taraf signifikansi 5\% didapatkan nilai $\mathrm{p}$ sebesar 0,278 (nilai $\mathrm{p}>0,05$ ). Hal ini menunjukkan bahwa tidak ada hubungan antara persepsi kerentanan terkena HIV dengan niat ibu hamil untuk tes HIV.

$\begin{array}{rrr}\text { Kerentanan } & \text { yang } & \text { dirasakan } \\ \text { (vulnerability) } & \text { merupakan } & \text { persepsi }\end{array}$
subyektif seseorang tentang resiko terkena penyakit. Seseorang akan bertindak untuk mengobati atau mencegah penyakit bila dirinya merasa rentan terhadap serangan penyakit tersebut. Kerentanan setiap individu berbeda, tergantung pada resiko individu yang dirasakan dari suatu keadaan tertentu. Persepsi yang baik dari seseorang akan mendorong seorang untuk melakukan tindakan pencegahan atau pengobatan. Hal ini tidak selaras dengan teori Model Kepercayaan Kesehatan atau Health Belief Model (HBM), dimana kerentanan yang dirasakan (perceived susceptibility) merupakan aspek yang kuat untuk dapat mengubah perilaku individu ke arah perilaku hidup sehat. Semakin besar faktor risiko yang dimiliki individu maka akan semakin besar pula upaya individu untuk mengubah perilakunya agar tidak terkena penyakit HIV.

\section{Keparahan Penyakit HIV}

Berdasarkan keparahan penyakit HIV pada Ibu hamil lebih banyak terdapat pada kelompok yang memiliki keparahan penyakit HIV kurang baik $(62,8 \%)$ dibandingkan yang memiliki keparahan penyakit HIV baik $(36,6 \%)$. Hasil uji statistik menggunakan uji Chi Square $\left(X^{2}\right)$ dengan taraf signifikansi 5\% didapatkan nilai $\mathrm{p}$ sebesar 0,005 (nilai $\mathrm{p}<0,05$ ). Hal ini menunjukkan bahwa ada hubungan antara persepsi keparahan penyakit HIV dengan niat ibu hamil untuk tes HIV.

Dari hasil analisis regresi logistik (Analisis Multivariat) Nilai adjusted OR 
atau exp (B) variabel persepsi keparahan penyakit HIV sebesar 2,973 dengan $\mathrm{p}=$ $0,009(\mathrm{p}<0,05)$ berarti persepsi keparahan yang baik mempunyai kemungkinan 2,973 kali berniat untuk tes HIV dibandingkan dengan persepsi keparahan yang kurang baik.

Hal ini sesuai dengan teori Health Belief Model yang menyatakan bahwa persepsi keparahan merupakan perasaan yang serius tertular penyakit atau meninggal karena tidak diobati. Sehingga menemukan kesulitan dalam pengobatan. Seseorang akan melakukan tindakan pengobatan atau pencegahan bila diancam oleh penyakit yang dirasakan lebih parah dibandingkan dengan penyakit yang dirasakan lebih ringan. Begitupula persepsi keparahan yang tinggi tentang penyakit HIV/AIDS akan membuat seseorang mengambil tindakan pencegahan atau deteksi dini terhadap penyakit tersebut, salah satunya melalui tes HIV.

\section{Efektivitas Mengikuti Tes HIV}

Berdasarkan efektivitas Ibu hamil mengikuti tes HIV lebih banyak terdapat pada kelompok yang memiliki efektivitas mengikuti tes HIV kurang baik (50\%) dibandingkan yang memiliki efektivitas mengikuti tes HIV baik (42\%). Hasil uji statistik menggunakan uji Chi Square $\left(X^{2}\right)$ dengan taraf signifikansi $5 \%$ didapatkan nilai $\mathrm{p}$ sebesar 0,374 (nilai $\mathrm{p}>0,05$ ). Hal ini menunjukkan bahwa tidak ada hubungan antara persepsi efektivitas mengikuti tes HIV dengan niat ibu hamil untuk tes HIV.

Respon efektif tindakan adalah bagaimana pendapat seseorang akan manfaat pemeriksaan tes HIV untuk mencegah penularan HIV/AIDS. Secara umum seseorang akan memanfaatkan layanan kesehatan apabila layanan tersebut lebih besar manfaatnya daripada pengorbanan yang harus dikeluarkan.

Menurut Rogers dalam teori proteksi motivasi menyatakan bahwa respon efektif (merupakan efektivitas yang menyangkut perilaku direkomendasikan dalam memindahkan atau mencegah gangguan atau bahaya yang mungkin timbul) mendorong terjadinya niat untuk melakukan tindakan atau niat untuk menghindar.

\section{Kemampuan Diri/Self Efficacy}

Berdasarkan kemampuan diri/self efficacy Ibu hamil lebih banyak terdapat pada kelompok yang memiliki self efficacy kurang baik $(56,9 \%)$ dibandingkan yang memiliki self efficacy baik (37,8\%). Hasil uji statistik menggunakan uji Chi Square $\left(X^{2}\right)$ dengan taraf signifikansi 5\% didapatkan nilai $\mathrm{p}$ sebesar 0,036 (nilai $\mathrm{p}<$ 0,05). Hal ini menunjukkan bahwa ada hubungan antara self efficacy dengan niat ibu hamil untuk tes HIV. 
Kemampuan diri (self efficacy) merupakan penilaian diri, apakah dapat melakukan tindakan yang baik atau buruk, tepat atau salah, bisa atau tidak bisa sesuai yang dipersyaratkan. Begitu halnya dengan ibu hamil, dimana ibu hamil yang memiliki kemampuan diri yang tinggi untuk melakukan tes HIV maka akan dirinya akan senantiasa bekerja keras untuk mewujudkannya yaitu melakukan tes HIV tersebut.

Ibu hamil yang mempunyai self efficacy maka akan lebih besar mencapai ke arah tujuan dan lebih besar untuk mengadopsi atau merekomendasi perilaku. Ibu yang memiliki keyakinan yang tinggi merasa yakin bahwa dia akan berhasil, sehingga dirinya akan melaksanakan tugasnya dengan cepat dan percaya diri. Dalam hal ini ibu hamil yang mempunyai usaha untuk meningkatkan kesehatan diri dan anaknya dengan cara mencegah ancaman penyakit HIV akan mampu melaksanakan usahanya dengan cara melakukan tes HIV.

\section{Peran Bidan dalam Memberikan}

\section{Penyuluhan}

Berdasarkan hasil penelitian pern bidan dalam memberikan penyuluhan lebih banyak terdapat pada kelompok yang mempersepsikan peran bidan kurang baik (60\%) dibandingkan yang mempersepsikan peran bidan baik (32,3\%). Hasil uji statistik menggunakan uji Chi Square $\left(X^{2}\right)$ dengan taraf signifikansi $5 \%$ didapatkan nilai $\mathrm{p}$ sebesar 0,002 (nilai $\mathrm{p}<0,05$ ). Hal ini menunjukkan bahwa ada hubungan antara peran bidan dalam memberikan penyuluhan dengan niat ibu hamil untuk tes HIV.

Dari hasil analisis regresi logistik (Analisis Multivariat) Nilai adjusted OR atau exp (B) variabel peran bidan dalam memberikan penyuluhan sebesar 3,053 dengan $\mathrm{p}=0,005(\mathrm{p}<0,05)$, berarti peran bidan yang baik mempunyai kemungkinan 3,053 kali berniat untuk tes HIV dibandingkan dengan peran bidan yang kurang baik.

Peran bidan dalam rangka mendorong ibu hamil untuk melakukan tes HIV dapat dikategorikan sebagai ProviderInitiated Testing and Counseling (PITC). PITC sendiri merupakan kebijakan pemerintah untuk dilaksanakan di layanan kesehatan yang berarti semua petugas kesehatan termasuk bidan harus menganjurkan tes HIV khususnya pada ibu hamil. Kegiatan memberikan anjuran dan pemeriksaan tes HIV perlu disesuaikan dengan prinsip bahwa pasien sudah mendapatkan informasi yang cukup dan menyetujui untuk tes HIV dan semua pihak menjaga kerahasiaan.

Setiap bidan yang melakukan perawatan antenatal di Puskesmas maupun di tempat perawatan antenatal lain 
disarankan untuk mengadakan pengamatan tentang kemungkinan adanya ibu hamil yang berisiko untuk menularkan penyakit HIV kepada bayinya. Penelitian ini sesuai teori Healt Belief Model (HBM), dimana peran bidan termasuk ke dalam komponen cues to action (Isyarat atau tanda-tanda untuk bertindak). Untuk mendapatkan tingkat penerimaan yang benar tentang kerentanan, kegawatan dan keuntungan tindakan, diperlukan isyarat-isyarat yang berupa faktor-faktor eksternal.

Peran bidan dalam memberikan penyuluhan merupakan salah satu faktor penguat terhadap dilakukannya tes HIV pada ibu hamil. Hal ini disebabkan tindakan seseorang sangat dipengaruhi oleh partisipasi petugas kesehatan dalam memberikan motivasi kepada masyarakat agar melakukan tindakan-tindakan yang berhubungan dengan kesehatan. Upaya penyuluhan secara berkesinambungan, terintegrasi dan terpadu yang dilakukan oleh bidan ditunjang dengan kemampuan bidan dalam mengelola program kesehatan dapat meningkatkan perilaku kesehatan pada ibu hamil. Dukungan dan dorongan dari bidan akan meningkatkan niat ibu hamil untuk melakukan tes HIV.

Dengan hasil tersebut diatas bisa disimpulkan bahwa ibu hamil dengan Pengetahuan tentang tes HIV baik, Persepsi keparahan penyakit HIV baik dan Peran bidan dalam memberikan penyuluhan (PITC) baik, maka mempunyai kemungkinan sebesar $83 \%$ untuk berniat tes HIV.

\section{SIMPULAN}

Dari hasil penelitian dan pembahasan yang telah diuraikan dapat disimpulkan bahwa Ibu hamil yang berniat untuk tes HIV sebanyak 54,4\%, sedangkan yang kurang niat sebanyak 45,6\%. Faktor paling berpengaruh secara signifikan terhadap niat ibu hamil untuk tes HIV, yaitu pengetahuan tentang tes HIV (OR atau exp (B) $=2,67)$, persepsi keparahan penyakit HIV (OR atau exp $(B)=2,973)$ dan peran bidan dalam memberikan penyuluhan (OR atau $\exp (\mathrm{B})=3,053)$. Faktor yang berhubungan dengan niat ibu hamil untuk tes HIV, yaitu pengetahuan tentang HIV/AIDS $(\mathrm{p}=0,022)$, pengetahuan tentang tes HIV $(\mathrm{p}=0,016)$, persepsi keparahan penyakit HIV $(\mathrm{p}=0,005)$, self efficacy $(\mathrm{p}=0,036)$ dan peran bidan dalam memberikan penyuluhan $(\mathrm{p}=0,002)$.

\section{KEPUSTAKAAN}

Ajzen I. Attitudes Personality And Behavior (Second Edition). Open University Press. New York. 2005.

Bandura A. Self Efficacy: The Exercise of a Control. Wikipedia. New York. 1997; 604.

Bowes JE. 2011. Communication and Community Development for Health 
Information: Construct and Models for Evaluation. Review Prepared for the National Network of Libraries of Medicine. Pasific Northwest Region. Seattle. University of Washington Seattle, WA. 276: 1-4.

Dao H, Mofenson LM, Ekpini R, Gilks CF, Barnhart M. 2007. International Recommendations on Antiretroviral Drugs for Treatment of HIV-Infected Women and Prevention of Motherto-Child HIV Transmission in Resource-Limited Settings: 2006 update. American Journal Of Obstetrics and Gynecology. 197: 4255.

Dinas Kesehatan Jawa Timur. 2010. Profil kesehatan Provinsi Jawa Timur. Jawa Timur.

Dinas Kesehatan Kabupaten Gresik. 2011. Profil Kesehatan Gresik. Gresik.

Direktorat Jenderal Bina Gizi dan Kesehatan Ibu dan Anak. 2012. Pedoman Pelayanan Antenatal Care (Edisi kedua). Kementerian Kesehatan Republik Indonesia.

Direktorat Jenderal Pengendalian Penyakit dan Penyehatan Lingkungan. 2014. Laporan Kasus HIV-AIDS di Indonesia sampai dengan 17 Oktober 2014., Kementerian Kesehatan Republik Indonesia. Jakarta.

Departemen Kesehatan Republik Indonesia. 2008. Modul Pelatihan
Pencegahan Penularan dari Ibu ke Bayi. Jakarta.

Judarwanto W. 2010. HIV Mengancam Anak Indonesia. Childrenhivaids. Wordpress. Jakarta.

Kementerian Kesehatan Republik Indonesia (KKRI). 2012. Pedoman Nasional Pencegahan penularan HIV dari Ibu ke Anak (PPIA). Jakarta.

Lusia K.A. 2015. (Kompas) Memutus Rantai Penularan HIV dari Ibu ke Bayi. Komunitas AIDS Indonesia 21 December 2006. Jakarta.

Maria D. dan Yuristianti G. 2000. Gender and Development Jayawijaya Watch Project-World Vision. Departemen Kesehatan Republik Indonesia. Jakarta.

Notoatmodjo S. 2003. Pendidikan dan Perilaku Kesehatan. Rineka Cipta. Jakarta.

Reeder SJ. dkk. 2011. Keperawatan Maternitas Kesejahteraan Wanita Bayi dan Keluarga. EGC. Jakarta.

United Nations Programme on HIV/AIDS (UNAIDS). 2012. Guidance on Provider-initiated HIV Testing and Counselling in Facilities. UNAIDS.

World Health Organization (WHO). 2012. Draf Working Paper: Antiretroviral Treatment as HIV Prevention Translating Research to Implementation in Asia. Cambodia. 
World Health Organization (WHO). 2011.

Progres HIV/AIDS WHO: Regional

Office For South-East Asia. WHO.

Sari AW. 2014. Faktor-faktor Yang

Berhubungan Dengan Niat Ibu

Hamil Untuk Memanfaatkan

Layanan VCT (Voluntary

Counseling And Testing) Di Wilayah

Kerja Puskesmas Ciputat Tahun

Kota Tangerang Selatan Provinsi

Banten Tahun 2014. (Skripsi)

Fakultas Kedokteran dan Ilmu

Kesehatan Universitas Islam Negeri

Syarif Hidayatullah Jakarta. Jakarta.

Sarwono S. 1997. Sosiologi Kesehatan

Beberapa Konsep Beserta

Aplikasinya. Gadjah Mada

University Press. Yogyakarta. 